\title{
Eskişehir 112 ìl Ambulans Servisi Çalışanlarında Bel Ağrısı ve Algılanan Stres Düzeylerinin Değerlendirilmesi
}

\author{
Ali KILINÇ 國 ${ }^{1}$, Seval ÇALIŞKAN PALA ${ }^{1}{ }^{1}$, Veli Görkem PALA ${ }^{2}{ }^{2}$, Didem ARSLANTAŞ國, \\ Alaettin ÜNSAL 1
}

Öz

Amaç: Çalışmada hastane öncesi acil sağlık hizmetleri (HÖASH) çalışanlarında en sık görülen kas-iskelet problemlerinden biri olan bel ağrısının ve algılanan stresin değerlendirilmesi amaçlanmıştır.

Gereç ve Yöntemler: Kesitsel tipteki bu çalışmada Eskişehir'deki HÖASH çalışanlarının \%77,5'ine ( $\mathrm{n}=378)$ ulaşıldı. Fonksiyonel Bel Ağrısı Skalası (FBAS) ve Algılanan Stres Ölçeği (ASÖ) kullanıldı. İstatistiki değerlendirmede Mann Whitney U, Kruskal Wallis, Spearman korelasyon ve binomial lojistik regresyon analizleri kullanılmıştır.

Bulgular: Çalışma grubunu oluşturanların \%55,1'i $(n=205)$ kadın olup yaş ortalaması \pm SS $32,15 \pm 7,52$ yıl idi. Çalışanların \%76,6'sı son 1 yılda bel ağrısı şikayeti olduğunu belirtti. Bel ağrısı riski, ön lisans ve üzeri öğrenim düzeyi olanlarda lise ve altına göre 1,97 (\%95 GA; 1,07-3,62), sağlık sektöründe 6-10 yıl ve 11 yıl üzeri çalışanlarda 5 yıl ve daha az çalışanlara göre sırasıyla 3,46 (\%95 GA; 1,66-7,22) ve 5,33 (\%95 GA; 2,52-11,27), 24 saat çalışanlarda 24 saatten az çalışanlara göre 3,65 (\%95 GA; 1,83-7,26), anne, baba ve kardeşlerinde bel ağrısı olanlarda olmayanlara göre 2,13 (\%95 GA; 1,19-3,80) ve algılanan stres düzeyleri yüksek olanlarda düşük olanlara göre 1,11 kat (\%95 GA; 1,03$1,20)$ daha fazlaydı. Genel sağlık durumunu iyi algılayanlarda orta ve kötü algılayanlara göre bel ağrısı 0,16 kat (\%95 GA; 0,04-0,58) daha az olarak bulundu. HÖASH çalışanlarının ASÖ ve FBAS'dan aldıkları puanlar arasında negatif yönde zayıf bir ilişki bulundu $(\mathrm{r}=-0,186, \mathrm{p}<0,001)$.

Sonuç: HÖASH çalışanları için bel ağrısı oldukça önemli bir sorundur. Personelin çalışma şartlarında iyileştirmeler yapılmasının ve ergonomi eğitimlerinin düzenlenmesinin yararlı olacağı kanısına varıldı.

Anahtar Kelimeler: Bel ağrısı; acil sağlık hizmetleri; mesleki stres.

\section{Evaluation of Low Back Pain and Perceived Stress Levels in Eskişehir 112 Provincial Ambulance Service Workers}

\section{ABSTRACT}

Aim: To evaluate low back pain (LBP) which is one of the most common musculoskeletal problems and perceived stress among prehospital emergency care (PEC) workers.

Material and method: In this cross-sectional study 77.5\% ( $\mathrm{n}=378)$ of PEC workers in Eskişehir were reached. Functional Back Pain Scale (FBPS) and Perceived Stress Scale (PSS) were used. Mann Whitney U, Kruskal Wallis, Spearman correlation and binomial logistic regression analysis were used.

Results: In the study group, $205(55.1 \%)$ were women, the mean age \pm SD was $32.15 \pm 7.52$ years and $285(76.6 \%)$ had LBP in the last year. The risk of LBP increased 1.97 times (95\% CI; 1.07-3.62) for having an undergraduate or higher education level compared to high school and below, 3.46 (95\% CI; 1.66-7.22) and 5.33 times (95\% CI; 2.52-11.27) for working in the health sector for 6-10 years and over 11 years respectively compared to 5 years and below, 3.65 times (95\% CI; 1.83-7.26) for working in 24 hour shifts compared to working less than 24 hours, 2.13 times (95\% CI; 1.19 3.80) for having mother, father and/or sibling(s) with low back pain compared to not having and 1.11 times (95\% CI; 1.03-1.20) for having high perceived stress compared to low. LBP was 0.16 times (95\% CI; 0.04-0.58) less in those who perceived their general health status as good.

Conclusion: LBP was an important problem for PEC workers. It would be beneficial to make improvements in the working conditions of the ambulance service personnel and to organize ergonomics trainings.

Keywords: Low back pain; emergency medical services; occupational stress. 


\section{GÍRIS}

Bel ağrısı, insanlık tarihi kadar eski olmasına rağmen modern tıpta yaşanan gelişmelerle azalmak yerine artış göstermiş bir sağlık sorunudur. Üzerinde pek çok çalışma yapılmış olsa da ağrının sebebi çoğu zaman bulunamamakta, bir takım nörolojik ve ortopedik hastalıklar suçlanmaktadır $(1,2)$.

Bir hastalık değil ancak semptom olarak karşımıza çıkan bel ağrısının, yaşam boyu görülme prevalansının \%84'e kadar çıkabildiği, kronik bel ağrısı prevalansının yaklaşık $\% 23$ olduğu ve bel ağrısı sebebiyle engellilik yaşayanların prevalansının \%11-12 olduğu bildirilmektedir (3). Ülkemizde yapılan bazı çalışmalarda ise yaşam boyu bel ağrısı görülme sıklığının \%51,0-86,3 arasında değiştiği bildirilmektedir (4-6). Oldukça sık görülen bel ağrısı; yaşam kalitesinde düşme, belirli işlerde çalışamama, iş gücü kaybı, ruhsal sorunlar, sağlık sistemi üzerinde yük oluşturması ve benzeri sebeplerden dolayı önemli bir halk sağlığı sorunu olarak kabul edilmektedir (7). Küresel Hastalık Yükü 2019 çalışmasında bel ağrısının Türkiye için birlikte en fazla ölüm ve sakatlığa sebep olma başlığında üçüncü sırada yer aldığı tespit edilmiştir (8). İçağasıŏlu ve arkadaşları da 2015 yılında yapılan bir çalışmada Türk toplumunun kronik bel ağrısı için yıllık doğrudan harcamasının 1080€ ve dolaylı harcamasının 5511€ olduğu ve bel ağrisına direkt olarak harcanan paradan çok daha fazlasının aslında farklı şekillerde kaybedildiği ifade edilmiştir (9). Bel ağrısının hem varlığını hem de şiddetini etkileyen yaş, cinsiyet, aile öyküsü gibi pek çok neden olmakla birlikte, kişinin yaptığı iş bu nedenler arasında en önemlilerindendir. Ancak çoğu zaman bel ağrısı iş yeriyle doğrudan ilişkilendirilememektedir. Bununla birlikte iş yerinde bel ağrısına sebep olabilecek fiziksel ve psikososyal pek çok risk faktörü bulunmaktadır. Bunlardan başlıcaları; ağır fiziksel işler, gece nöbetleri, ağır kaldırma, eğilme, bükülme, çekme ve itme hareketleridir (10-12).

Hastane öncesi acil hizmetleri sunmakla yükümlü olan ambulans servisi çalışanları da bu sebeplerle önemli bir risk altındadır. Sadece hasta bakımı ve taşınması gibi ağır fiziksel koşullar değil, ölümlü ve yaralanmalı büyük kazalar, doğal afetler ve silahlı çatışmalar gibi koşullarda çalışmaları psikolojik olarak da hastane öncesi acil hizmet sunucularını yıpratmaktadır. Fiziksel şartların yanı sıra, bu ağır psikolojik baskının da, acil servis çalışanlarında bel ağrısı görülme sıklığını arttırdığı düşünülmektedir(13,14).

Çalışmamızda, Eskişehir ilinin ambulans servisi çalışanlarında bel ağrısı ve sebep olduğu fonksiyon kaybı ile algılanan stres düzeylerinin değerlendirilmesi amaçlanmıştır.

\section{GEREC VE YÖNTEMLER}

Çalışma 01 Ocak 2020-15 Ocak 2020 tarihleri arasında Eskişehir 112 İl Ambulans Servisi çalışanları üzerinde gerçekleştirilmiş kesitsel tipte bir çalışmadır. Çalışmanın gerçekleştirilebilmesi için Eskişehir Osmangazi Üniversitesi'nden 25403353 say1l ve 10.12.2019 tarihli etik kurul onayı alındıktan sonra Eskişehir İl Sağlık Müdürlüğü ve Eskişehir 112 İl Ambulans Servisi Başhekimliği'nden gerekli idari izinler alınmıştır.
Çalışmada veri toplanabilmesi için literatürden de faydalanılarak bir anket form hazırlandı (15-17). Anket form, kişilerin bazı sosyodemografik özelliklerini (yaş, cinsiyet, medeni durum, vb.), bel ağrısı ile ilgili olduğu düşünülen bazı değişkenleri ve Fonksiyel Bel Ağrısı Skalası ile Algılanan Stres Ölçeği sorularını içermektedir. Çalışmanın yapılabilmesi için Eskişehir 112 İl Ambulans Servisi çalışanlarının tamamına ulaşılması hedeflenmiştir. Eskişehir 112 İl Ambulans Servisi, 15'i şehir merkezinde ve 14 'ü ise perifer ilçelerde olmak üzere toplam 29 tane Acil Sağlık Hizmetleri İstasyonu ile bir tane Komuta Kontrol Merkezinden oluşmaktadır.

Eskişehir 112 İl Ambulans Servisi bünyesinde 240 acil tıp teknisyeni, 138 ambulans ve acil bakım teknikeri (paramedik), 43 doktor, 17 şoför, 6 sağlık memuru, 4 ebe/hemşire ve 32 büro çalışanı (16 hizmetli, 1 memur, 11 veri hazırlama kontrol işletmeni ve idari büro görevlisi, 1 tıbbi teknolog, 1 tıbbi sekreter, 2 tekniker/teknisyen) olmak üzere toplamda 480 il ambulans servisi çalışanı görev yapmaktadır. Çalışmada Eskişehir 112 İl Ambulans Servisi'nde görev yapmakta olan tüm sağlık çalışanlarında gerçekleştirilmesi hedeflenmiş olup, \%77.5'ine ulaşıldı.

Çalışma Eskişehir 112 İl Ambulans Servisi Başhekimliği koordinasyonuyla uygun gün ve saatler belirlenerek randevular alınmıştır. Randevu gün ve saatinde birimlere gidilerek uygun bir alanda görüşmeler yapılmıştır. Görüşme sırasında çalışanlar araştırma konusu ve amacı hakkında bilgilendirildikten sonra çalışmaya katılmayı kabul edenlerin sözlü onamları alınarak çalışmaya dâhil edilmiştir. Daha önceden hazırlanmış olan anket formlar yüz yüze görüşme yöntemi ile araştırmacı tarafından doldurulmuş ve bu işlem yaklaşık olarak 15-20 dakika sürmüştür.

Çalışmada, bel ağrısı kaynaklı fonksiyon kaybını değerlendirmek için Fonksiyel Bel Ağrısı Skalası (FBAS) kullanılmıştır. Fonksiyel Bel Ağrısı Skalası 2000 yılında Stratford ve arkadaşları tarafından geliştirilmiştir. FBAS, 12 önermeden oluşan 6'l likert tipinde bir ölçme aracıdır. "Aktiviteyi yapmak mümkün değil" 0 puan, “Aşırı zor" 1 puan, "Epey zor" 2 puan, "Orta zorlukta" 3 puan, "Biraz zor" 4 puan ve "Zor değil" 5 puan şeklinde skorlanmakta olup skaladan alınabilecek puanlar 0 ile 60 arasında değişmektedir ve alınan puan arttıkça bel ağrısı azalmaktadır (18). FBAS'ın Türkçe'ye uyarlanması ve geçerlik-güvenirlik çalışması Koç ve Bayar tarafından 2017 yılında yapılmıştır (19).

Eskişehir 112 İl Ambulans Servisi çalışanlarının stres düzeylerini ölçmek için ise Algılanan Stres Ölçeği (ASÖ) kullanılmıştır. ASÖ, 1983 yılında Cohen ve arkadaşları tarafından oluşturulan ve stres algısını ölçmek için yaygın olarak kullanılan bir araçtır. Toplam 14 sorudan oluşan ölçekte katılımcılara geçtiğimiz ay hissettiği duygularla ilgili sorular sorulur. Sorular 0 (Hiçbir zaman)-4 (Çok s1k) şeklinde cevaplanır. Skorlamada olumlu ifade içeren $(4,5,6,7,9,10,13)$ sorularda puanlama ters olarak yapılır. (Hiçbir zaman-4, Çok sık-0) Testten alınabilecek en yüksek puan 56'dır. Puan arttıkça algılanan stres artmaktadır (20). Mehmet Eskin ve arkadaşları 2013 yılında yaptıkları çalışmada, Türkçe ASÖ’nün insanların öznel stres algılarını ölçmek üzere kullanılabilecek nitelikte geçerli ve güvenilir bir ölçüm aracı olduğunu bildirmiştir (21). 
Çalışmadan elde edilen veriler bilgisayar ortamına aktarılarak SPSS v15 (SPSS, San Diego, CA) istatistik paket programında değerlendirildi. Verilerin normal dağılıma uymadığı Shapiro-Wilk testi ile belirlendikten sonra gruplar arası karşılaştırmalarda Mann Whitney U, Kruskal Wallis ve Spearman korelasyon analizleri kullanılmıştır. İstatistiksel anlamlılık değeri olarak $\mathrm{p} \leq 0.05$ kabul edilmiştir.

\section{BULGULAR}

Çalışma grubunu oluşturanların 205'i $(\% 55,1)$ kadın, 167 'si $(\% 44,9)$ erkek olup yaş ortalaması $32,15 \pm 7,52$ (min:17;maksimum:60) yıl idi. Çalışma grubunu oluşturan hastane öncesi acil sağlık servisi personelinin 285'i $(\% 76,6)$ son 1 yıl içerisinde bel ağrısı şikâyetinin olduğunu belirtti. Çalışmada 30 yaşın üzerinde olanlarda ve önlisans ve üstü ögrenim düzeyine sahip olanlarda daha sık bel ağrısı şikâyeti mevcuttu. Bekârlarda, evli olanlara göre ve idari/ofis işleri gibi diğer mesleklere sahip olanlarda diğer meslek gruplarına göre bel ağrısı daha az görülmekteydi. Çalışma grubunda bel ağrısı şikayeti olan ve olmayanların bazı sosyodemografik özelliklere göre dağılımı Tablo 1'de verilmiştir.

Tablo 1. Çalışma grubunda bel ağrısı şikayeti olan ve olmayanların bazı sosyodemografik özelliklere göre dağılımı

\begin{tabular}{|c|c|c|c|c|c|}
\hline \multirow{2}{*}{\multicolumn{2}{|c|}{$\begin{array}{l}\text { Bazı Sosyodemografik } \\
\text { Özellikler }\end{array}$}} & \multicolumn{3}{|c|}{ Bel Ağrısı } & \multirow{4}{*}{$\begin{array}{c}\text { İstatistik } \\
\text { sel } \\
\text { Analiz } \\
\text { X }^{2} ; p \\
13,108 ; \\
<0,001\end{array}$} \\
\hline & & & & & \\
\hline \multirow{2}{*}{$\begin{array}{l}\text { Yaş } \\
\text { Grubu }\end{array}$} & $<30$ & $54(32,1)$ & $114(67,9)$ & $168(45,2)$ & \\
\hline & $>30$ & $33(16,2)$ & $171(83,8)$ & $204(54,8)$ & \\
\hline \multirow{2}{*}{ Cinsiyeti } & Kadın & $42(20,5)$ & $163(79,5)$ & $205(55,1)$ & \multirow{2}{*}{$\begin{array}{c}2,142 \\
0,143\end{array}$} \\
\hline & Erkek & $45(26,9)$ & $122(73,1)$ & $167(44,9)$ & \\
\hline \multirow{3}{*}{$\begin{array}{l}\text { Medeni } \\
\text { Durum }\end{array}$} & Evli* & $39(16,8)$ & $193(83,2)$ & $232(62,4)$ & \multirow{3}{*}{$\begin{array}{r}15,209 \\
<0,001\end{array}$} \\
\hline & Bekâr* & $45(34,9)$ & $84(65,1)$ & $129(34,7)$ & \\
\hline & $\begin{array}{l}\text { Eşinden } \\
\text { ayrılmış/ } \\
\text { eşi ölmüş }\end{array}$ & $3(27,3)$ & $8(72,7)$ & $11(3,0)$ & \\
\hline \multirow[b]{2}{*}{$\begin{array}{l}\text { Öğrenim } \\
\text { Durumu }\end{array}$} & Lise ve altı & $35(36,8)$ & $60(63,2)$ & $95(25,5)$ & \multirow[b]{2}{*}{$\begin{array}{l}12,891 \\
<0,001\end{array}$} \\
\hline & $\begin{array}{l}\text { Önlisans ve } \\
\text { üstü }\end{array}$ & $52(18,8$ & $225(81,2)$ & $277(74,5)$ & \\
\hline \multirow{7}{*}{ Meslek } & Doktor & $5(15,2)$ & $28(84,8)$ & $33(8,9)$ & \multirow{7}{*}{$\begin{array}{c}18,467 \\
0,005\end{array}$} \\
\hline & Hemşire & $0(0,0)$ & $2(100,0)$ & $2(0,5)$ & \\
\hline & $\begin{array}{l}\text { Sağlık } \\
\text { Memuru }\end{array}$ & $3(21,4)$ & $11(78,6)$ & $14(3,8)$ & \\
\hline & Paramedik & $29(22,7)$ & $99(77,3)$ & $128(34,4)$ & \\
\hline & $\begin{array}{l}\text { Acil Tip } \\
\text { Teknisyeni }\end{array}$ & $38(23,0)$ & $127(77,0)$ & $165(44,4)$ & \\
\hline & Şoför & $2(13,3)$ & $13(86,7)$ & $15(4,0)$ & \\
\hline & $\begin{array}{l}\text { Diğer(İdari/ } \\
\text { ofis işleri } \\
\text { çalışanları) } \\
*\end{array}$ & $10(66,7)$ & $5(33,3)$ & $15(4,0)$ & \\
\hline \multirow{3}{*}{ Aile Tipi } & $\begin{array}{l}\text { Çekirdek } \\
\text { Aile }\end{array}$ & $79(24,0)$ & $250(76,0)$ & $329(88,4)$ & \multirow{3}{*}{$\begin{array}{c}0,708 \\
0,702\end{array}$} \\
\hline & Geniş Aile & $7(19,4)$ & $29(80,6)$ & $36(9,7)$ & \\
\hline & $\begin{array}{l}\text { Parçalanmı } \\
\text { ş Aile }\end{array}$ & $1(14,3)$ & $6(85,7)$ & $7(1,9)$ & \\
\hline \multirow{3}{*}{$\begin{array}{l}\text { Gelir } \\
\text { Durumu }\end{array}$} & Kötü & $2(25,0)$ & $6(75,0)$ & $8(69,9)$ & \multirow{3}{*}{$\begin{array}{c}0,404 \\
0,817\end{array}$} \\
\hline & Orta & $63(24,2)$ & $197(75,8)$ & $260(69,9)$ & \\
\hline & İyi & $22(21,2)$ & $82(78,8)$ & $104(28,8)$ & \\
\hline \multicolumn{2}{|l|}{ Toplam } & $87(23,4)$ & $285(76,6)$ & $372(100,0)$ & \\
\hline
\end{tabular}

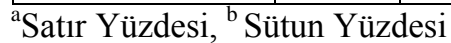

Çalışmada sağlık sektöründe ve hastane öncesi acil servislerde 5 yıldan daha az süre çalışanlarda, başhekimlik ve idare gibi komuta ve istasyon dışındaki birimlerde çalışanlarda, çalışma süresince ayakta 6 saatten az kalanlarda, genel sağlık durumunu iyi olarak algılayanlarda ve hekim tanılı kronik hastalığı olmayanlarda bel ağrısı görülme oranı daha az olarak bulundu. Bir vardiyada $11 \mathrm{kez}$ veya daha fazla ağırlık kaldırdığ ağrısı şikâyeti olanlarda ve 24 saatlik vardiya ile çalışanlarda ise bel ağrısının daha sık olduğu bulundu. Çalışma grubunda bel ağrısı olan ve olmayanların bel ağrısı ile ilişkili olduğu düşünülen bazı değişkenlere göre dağılımı Tablo 2'de verilmiştir.

Çalışma grubunda son 1 yılda bel ağrısı şikayeti olan sağlık çalışanlarından, \%45,6 (n=160)'sı bel ağrısına sebep olan eylemi kaldırma, $\% 23,3(n=82)$ 'ü ayakta durma, \%23,1(n=81)'i eğilme/bükülme ve $\% 8,0(n=28)$ 'i oturma eylemleri olarak belirtti. Çalışma grubundaki kişilerin bel ağrısı ile en sık başa çıkma yönteminin ise \%51,9 (n=160) ile doktora gitmek olduğu saptandi. Çalışma grubundakilerin bel ağrısıyla başa çıkmak için kullandığ1 yöntemlerin dağılımı Tablo 3 'te verilmiştir.

Çalışmaya katılan sağlık çalışanlarının Algılanan Stres Ölçeği (ASÖ)'den aldıkları puanlar 18 ile 42 arasında değişmekte olup ortalaması $29,58 \pm 3,83$ ve ortancası 30 puan olarak bulundu. Çalışmada son 1 yılda bel ağrısı şikâyeti olduğunu belirten 285 kişinin Fonksiyonel Bel Ağrısı Skalası (FBAS)'ndan aldıkları puanlar ise 5 ile 59 arasında değişmekte olup ortalaması 42,18 $\pm 0,68$ ve ortancası 44 puan idi. Çalışma grubunda son 1 yılda bel ağrısı olanların ASÖ’den aldığı puanlar 18 ile 40 arasında değişmekte olup ortancası 29 ve bel ağrısı olmayanların ASÖ'den aldıkları puanlar 18 ile 42 arasında değişmekte olup ortancası 30 olarak bulundu. Bel ağrısı olan ve olmayanların ASÖ’den aldıkları puanlar Mann-Whitney U testi ile incelendiğinde anlamlı bir fark olduğu görüldü $(\mathrm{p}<0,001)$. Çalışma grubunun ASÖ’den aldıkları puanların bel ağrısı varlığına göre dağılımı Tablo 4'te gösterilmiştir. Hastane öncesi sağlık çalışanlarının algılanan stres ve fonksiyonel bel ağrısı ölçeklerinden aldıkları puanlar arasında negatif yönde zayıf bir ilişki bulundu ( $\mathrm{r}=-0,186, \quad \mathrm{p}<0,001)$. Çalışma grubundaki bireylerin ASÖ ve FBAS'tan aldıkları puanların arasındaki ilişki Şekil 1'de gösterilmiştir. Çalışma grubunda gerçekleştirilen çok değişkenli lojistik regresyon analizinde bel ağrısı riski öğrenim durumu ön lisans ve üzeri olanlarda, lise ve altı öğrenim düzeyine sahip olanlara kıyasla 1,97 kat (\%95 GA 1,07-3,62), sağlık sektöründe 6-10 yıl ve 11 yıl ve üzeri çalışanlarda 5 yıldan az çalışanlara kıyasla 3,46 (\%95 GA 1,66-7,22) ve 5,33 (\%95 GA 2,52-11,27) kat, 24 saatlik vardiyalarla çalışanlarda 24 saatten az çalışanlara kıyasla 3,65 (\%95 GA 1,83-7,26) kat, anne, baba ve kardeşte bel ağrıs1 olanlarda olmayanlara kıyasla 2,13 (\%95 GA 1,19-3,80) kat artiyordu. Bunun yanı sira stresin artmasiyla birlikte bel ağrısı riski 1,11 kat (\%95 GA 1,03-1,20) artıyorken genel sağlık durumunu iyi olarak algılayanlarda kötü olarak algılayanlara kıyasla 0,16 kat (\%95 GA 0,04-0,58) azalıyordu. Tablo 5'te Çok değişkenli lojistik regresyon modelinin sonuçları verilmiştir 
Tablo 2. Çalışma grubunda bel ağrısı olan ve olmayanların bel ağrısı ile ilişkili olduğu düşünülen bazı özelliklere göre dağılımı

\begin{tabular}{|c|c|c|c|c|c|}
\hline \multicolumn{2}{|c|}{ Bel Ağrısı ile İlişkili Bazı Değişkenler } & \multicolumn{3}{|c|}{ Bel Ağrısı } & $\begin{array}{c}\text { İstatistiksel Analiz } \\
\qquad \mathbf{X}^{2} ; \mathbf{p}\end{array}$ \\
\hline \multirow{3}{*}{ Çalıştığı Birim } & Komuta & $\begin{array}{c}\begin{array}{c}\text { Yok } \\
\mathbf{n}(\%)^{\mathbf{a}}\end{array} \\
13(21,0)\end{array}$ & $\begin{array}{c}\begin{array}{c}\text { Var } \\
\mathbf{n}(\%)^{\mathbf{a}}\end{array} \\
49(79,0)\end{array}$ & $\begin{array}{c}\text { Toplam } \\
\mathbf{n}(\%)^{\mathbf{b}} \\
62(16,7)\end{array}$ & \multirow{3}{*}{10,$878 ; 0,004$} \\
\hline & İstasyon & $60(21,4)$ & $221(78,6)$ & $281(75,5)$ & \\
\hline & Diğer* & $14(48,3)$ & $15(51,7)$ & $29(7,8)$ & \\
\hline \multirow{3}{*}{$\begin{array}{l}\text { Sağlık } \\
\text { Sektöründe } \\
\text { Çalışma Süresi }\end{array}$} & $<5 \mathrm{Y}_{11}{ }^{*}$ & $32(50,0)$ & $32(50,0)$ & $64(17,2)$ & \multirow{3}{*}{32,$382 ;<0,001$} \\
\hline & $>5 \mathrm{Y}_{11}, \leq 10 \mathrm{Y}_{11}$ & $30(21,4)$ & $110(78,6)$ & $140(37,6)$ & \\
\hline & $>10$ Yil & $25(14,9)$ & $143(85,1)$ & $168(45,2)$ & \\
\hline \multirow{3}{*}{$\begin{array}{l}\text { Hastane Öncesi } \\
\text { Acil Serviste } \\
\text { Çalışma Süresi }\end{array}$} & $<5 \mathrm{Y}_{11}{ }^{*}$ & $37(44,0)$ & $47(56,0)$ & $84(22,6)$ & \multirow{3}{*}{26,$845 ;<0,001$} \\
\hline & $>5$ Y $11, \leq 10$ Yil & $31(19,6)$ & $127(80,4)$ & $158(42,5)$ & \\
\hline & $>10 \mathrm{Y}_{11}$ & $19(14,6)$ & $111(85,4)$ & $130(34,9)$ & \\
\hline \multirow{2}{*}{$\begin{array}{l}\text { Sigara İçme } \\
\text { Durumu }\end{array}$} & İçiyor & $47(20,7)$ & $180(79,3)$ & $227(61,0)$ & \multirow{2}{*}{2,$338 ; 0,126$} \\
\hline & İçmiyor & $40(27,6)$ & $105(72,4)$ & $145(39,0)$ & \\
\hline \multirow{2}{*}{$\begin{array}{l}\text { Alkol Tüketme } \\
\text { Durumu }\end{array}$} & Tüketiyor & $21(28,4)$ & $53(71,6)$ & $74(19,9)$ & \multirow{2}{*}{1,$284 ; 0,257$} \\
\hline & Tüketmiyor & $66(22,1)$ & $232(77,9)$ & $298(80,1)$ & \\
\hline \multirow{2}{*}{ Çalışma Saatleri } & 24 Saat Çalışanlar & $59(19,0)$ & $251(81,0)$ & $310(83,3)$ & \multirow{2}{*}{19,$687 ;<0,001$} \\
\hline & 24 Saatten Az Çalışanlar & $28(45,2)$ & $34(54,8)$ & $62(16,7)$ & \\
\hline \multirow{4}{*}{$\begin{array}{l}\text { Ayakta Geçirilen } \\
\text { Süre }\end{array}$} & 0-6 Saat* & $27(32,5)$ & $56(67,5)$ & $83(22,3)$ & \multirow{4}{*}{8,$321 ; 0,040$} \\
\hline & 6-12 Saat & $43(24,2)$ & $135(75,8)$ & $178(47,8)$ & \\
\hline & 12-18 Saat & $12(17,1)$ & $58(82,9)$ & $70(18,8)$ & \\
\hline & 18-24 Saat & $5(12,2)$ & $36(87,8)$ & $41(11,1)$ & \\
\hline \multirow{3}{*}{$\begin{array}{l}\text { Bir Vardiyada } \\
\text { Ağır Kaldırma } \\
\text { Sayısı }\end{array}$} & 0-5 Defa & $47(28,1)$ & $120(71,9)$ & $167(44,9)$ & \multirow{3}{*}{ 7,385; $\mathbf{0 , 0 2 5}$} \\
\hline & 5-10 Defa & $34(23,0)$ & $114(77,0)$ & $148(39,8)$ & \\
\hline & 11 Defa ve üzeri* & $6(10,5)$ & $51(89,5)$ & $57(15,3)$ & \\
\hline \multirow{3}{*}{$\begin{array}{l}\text { Genel Sağlık } \\
\text { Durumu }\end{array}$} & Kötü & $4(10,3)$ & $35(89,7)$ & $39(10,5)$ & \multirow{3}{*}{39,$473 ;<0,001$} \\
\hline & Orta & $22(12,2)$ & $158(87,8)$ & $480(48,4)$ & \\
\hline & İyi* & $61(39,9)$ & $92(60,1)$ & $153(41,1)$ & \\
\hline \multirow{2}{*}{$\begin{array}{l}\text { Kronik Hastalık } \\
\text { Varlığı }\end{array}$} & Yok & $81(26,6)$ & $223(73,4)$ & $304(81,7)$ & \multirow{2}{*}{ 9,850; 0,002} \\
\hline & Var & $6(8,8)$ & $62(91,2)$ & $68(18,3)$ & \\
\hline Psikiyatrik & Yok & $84(23,9)$ & $268(76,1)$ & $352(94,6)$ & Fichor. 058 \\
\hline Hastalık Varlığı & Var & $3(15,0)$ & $17(85,0)$ & $20(5,4)$ & 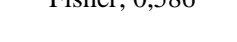 \\
\hline Anne, Baba ve & Yok & $49(36,6)$ & $85(63,4)$ & $134(36,0)$ & \\
\hline $\begin{array}{l}\text { Kardeşlerde Bel } \\
\text { Ağrısı Varlığı }\end{array}$ & Var & $38(16,0)$ & $200(84,0)$ & $238(64,0)$ & 20,$306 ;<0,001$ \\
\hline Kaza ve/veya & Yok & $67(25,9)$ & $192(74,1)$ & $259(69,6)$ & $2931 \cdot 0087$ \\
\hline Travma Öyküsü & Var & $20(17,7)$ & $93(82,3)$ & $113(30,4)$ & \\
\hline & Zayıf & $6(40,0)$ & $9(60,0)$ & $15(4,0)$ & \\
\hline Vücut Kitle & Normal Kilolu & $40(20,5)$ & $155(79,5)$ & $195(52,4)$ & $4826 \cdot 018$ \\
\hline İndeksi & Fazla Kilolu & $36(27,1)$ & $97(72,9)$ & $133(35,8)$ & $+, 0<0,0,10 J$ \\
\hline & Obez & $5(17,2)$ & $24(82,8)$ & $29(7,8)$ & \\
\hline Toplam & & $87(23,4)$ & $285(76,6)$ & $372(100,0)$ & \\
\hline
\end{tabular}

a Satır Yüzdesi, b Sütun Yüzdesi 
Tablo 3. Çalışma grubundakilerin bel ağrısıyla başa çıkmak için kullandığı yöntemlerin dağılımı

\begin{tabular}{|l|c|c|}
\hline $\begin{array}{l}\text { Bel Ağrısıyla Başa Çıkmak İçin } \\
\text { Kullanılan Yöntem }\end{array}$ & $\mathbf{n}$ & \% \\
\hline Doktora Gitmek & 160 & 51,9 \\
\hline Alternatif Tıp Yöntemleri Uygulamak & 18 & 5,8 \\
\hline Kırık-çıkıkçıara gitmek & 7 & 2,2 \\
\hline Hiçbir Şey Yapmamak & 88 & 28,5 \\
\hline Diğer & 35 & 11,3 \\
\hline Toplam & $\mathbf{3 0 8}$ & $\mathbf{1 0 0}$ \\
\hline
\end{tabular}

*Sayılar kişiler üzerinden değil cevaplar üzerinden değerlendirilmiştir

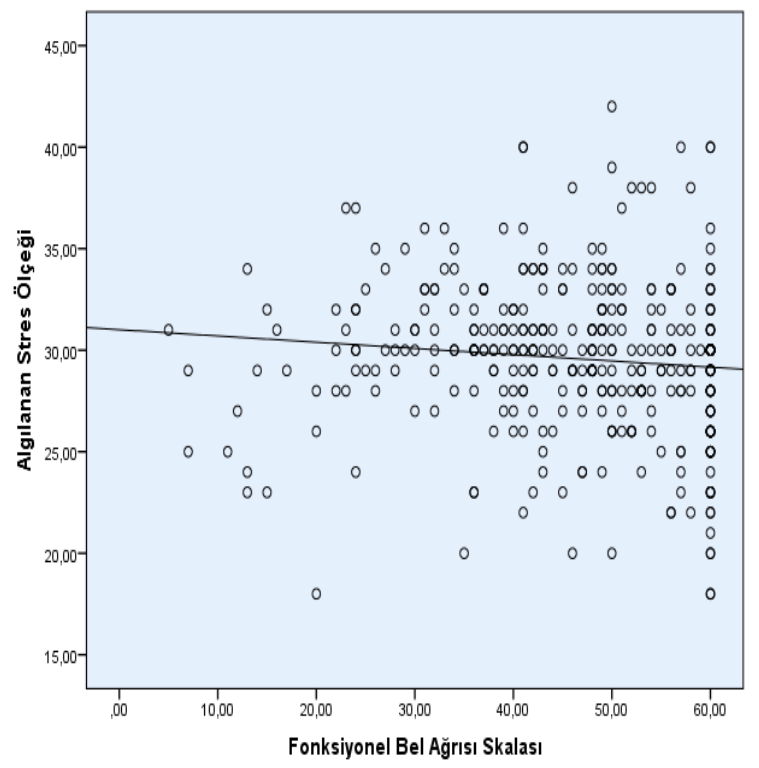

Şekil 1. Çalışma grubundaki bireylerin ASÖ ve FBAS'tan aldıkları puanların arasındaki ilişki

\section{TARTIŞMA}

Bel ağrısı, gün geçtikçe artan bir şekilde toplumun büyük bir kesimini fiziksel, ruhsal ve ekonomik olarak etkileyen önemli bir halk sağlığı sorunu haline gelmiştir. Gittikçe kalabalıklaşan ve yaşlanan nüfus göz önünde bulundurulduğunda, bel ağrisı sorunun önemi daha da artmaktadır. Çalışma grubunda yaklaşık dörtte üçünün son bir yılda bel ağrısı şikayeti olduğu bulundu. Ülkemizde sağlık çalışanlarında gerçekleştirilen çeşitli çalışmalarda bel ağrısı görülme oranının \%53-69 arasında değiştiği bildirilmiştir (22-24). Hastane öncesi acil servis çalışanlarında daha yüksek bel ağrısı görülmesi, fiziki çalışma şartlarının daha zorlayıcı olmasından kaynaklanmış olabilir.
Tablo 4. Çalışma Grubunun ASÖ’den aldıkları puanların bel ağrısı varlığına göre karşılaştırılması

\begin{tabular}{|l|c|c|c|}
\hline $\begin{array}{l}\text { Bel Ağrısı } \\
\text { Varlığı }\end{array}$ & $\mathbf{n}(\boldsymbol{\%})$ & $\begin{array}{c}\text { ASÖ Ortanca } \\
\text { Puanı } \\
(\mathbf{m i n} \text { max })\end{array}$ & $\begin{array}{c}\text { İstatistiksel Analiz } \\
\mathbf{U ; p}\end{array}$ \\
\hline Yok & $87(23,4)$ & $29,0(18,0-40,0)$ & \\
\hline Var & $285(76,6)$ & $30,0(18,0-42,0)$ & $\mathbf{3 , 8 8 4 ; < 0 , 0 0 1}$ \\
\hline
\end{tabular}

Tablo 5. Çok değişkenli lojistik regresyon modelinin sonuçları (step final)

\begin{tabular}{|c|c|c|c|c|c|}
\hline Değişkenler & $\beta$ & SH & $\mathrm{P}$ & OR & GA \\
\hline \multicolumn{6}{|c|}{ Öğrenim Durumu (Referans: Lise ve altı) } \\
\hline $\begin{array}{l}\text { Ön Lisans ve } \\
\text { üzeri }\end{array}$ & 0,678 & 0,311 & 0,030 & 1,97 & $1,07-3,62$ \\
\hline \multicolumn{6}{|c|}{ Sağlık Sektöründe Çalışma Süresi (Referans: 5 yıldan az) } \\
\hline $6-10$ y1l & 1,244 & 0,375 & 0,001 & 3,46 & $1,66-7,22$ \\
\hline 11 y1l ve üzeri & 1,674 & 0,382 & $<0,001$ & 5,33 & $2,52-11,27$ \\
\hline \multicolumn{6}{|c|}{ Çalışma Saatleri (Referans: 24 saatten az çalışma) } \\
\hline 24 saat çalışanlar & 1,295 & 0,351 & $<0,001$ & 3,65 & $1,83-7,26$ \\
\hline \multicolumn{6}{|c|}{ Genel Sağlık Durumu (Referans: Kötü) } \\
\hline Orta & $-0,686$ & 0,670 & 0,306 & 0,50 & $0,13-1,87$ \\
\hline İyi & $-1,806$ & 0,646 & 0,005 & 0,16 & $0,04-0,58$ \\
\hline \multicolumn{6}{|c|}{ Anne, baba ve kardeşlerde bel ağrısı varlığı (Referans: Yok) } \\
\hline Var & 0,758 & 0,295 & 0,010 & 2,13 & $1,19-3,80$ \\
\hline \multicolumn{6}{|l|}{ Algilanan Stres } \\
\hline Stres düzeyi & 0,109 & 0,038 & 0,004 & 1,11 & $1,03-1,20$ \\
\hline Sabit (Constant) & $-2,559$ & 1,279 & 0,045 & & \\
\hline
\end{tabular}

Bel ağrısı tüm yaş gruplarında görülebilmekle birlikte, insidansının 30'lu yaşlarda en yüksek düzeye ulaştığı belirtilmektedir (25). Çalışmada yapılan çoklu analiz sonucunda bel ağrısı ve yaş arasında bir ilişki bulunamasa da tekli analizlerde beklendiği üzere bel ağrısı 30 yaş üzerinde daha sık bulundu. Yapılan çeşitli çalışmalarda yaşın ilerlemesinin bel ağrısı sıklığını ve bel ağrısı kaynaklı fonksiyon kaybını artırdığı bildirilmektedir $(26,27)$. Buna karşın yaş ve bel ağrısı arasında herhangi bir ilişki saptanamadığı da bildirilmiştir (28). Çalışmalarda bel ağrısını değerlendirirken farklı ölçüm araçlarının kullanılması bu sonucu ortaya çıkarmış olabilir. 
Düşük öğrenim düzeyine sahip sağlık çalışanlarının bel ağrısı hakkında bilgi düzeylerinin ve farkındalıklarının daha yetersiz olduğu ve bunun sonucunda da daha sik bel ağrısı ile mücadele etmek durumunda kaldıkları bildirilmektedir (29). Ayrıca daha yüksek öğrenim düzeyine sahip sağlık çalışanlarının bel ağrısına sebep olacak işleri daha az yapıyor olması da bu durumu desteklemektedir (30). Ancak çalışmamızda önlisans ve üzeri öğrenim düzeyine sahip sağlık çalışanlarında, lise ve altı öğrenim düzeyine sahip olanlara göre bel ağrısının daha sık görüldüğü bulundu. Çalışmada bel ağrısı varlığının kişilerin kendi algılarına göre değerlendirilmesi, öğrenim düzeyi ve farkındalıkları yüksek sağlık çalışanlarının bel ağrısı olanlar içinde daha fazla sayıda temsil edilmesinden kaynaklanmış olabilir.

Sağlık hizmetleri arasında hastane öncesi acil servis hizmeti hem fiziksel hem de psikolojik açıdan oldukça yıpratıcı bir yapıya sahiptir. Uzun yıllar boyunca zorlu koşullarda çalışmanın sonuçlarından birisi de bel ağrısı ve buna bağlı günlük işlevleri yerine getirmede yaşanılan sorunlardır (31). Araştırmada sağlık sektöründe ve hastane öncesi acil servis hizmetlerinde uzun yıllar çalışan personellerde bel ağrısı daha sık görülmekteydi. Imani ve arkadaşları da benzer sonuç bildirmektedir (32). Ancak çalışma süresi ve bel ağrısı arasında ilişki bulunamadığını raporlayan araştırmalar da mevcuttur $(28,33)$. Çalışmalarda bildirilen sonuçların farklılığının nedenleri arasında araştırmaların farklı kültürlere sahip çalışma grupları üzerinde yapılması sayılabilir.

Hastane öncesi acil servis sunumunun en önemli parçalarından birisi hastaların düzgün ve hızlı bir şekilde nakledilmesidir. $\mathrm{Bu}$ işlem sırasında yapılan eğilme, bükülme ve ardından hastayı kaldırma eylemleri bel ağrısı için oldukça önemli risk faktörleri arasında sayılmaktadır (34). Çalışmamızda da beklendiği gibi daha fazla ağır kaldırdığını belirten çalışanlarda bel ağrısının daha fazla olduğu bulundu. Coenen ve arkadaşlarının gerçekleştirdiği meta-analizde de ağırlık kaldırmanın sağlık çalışanlarında bel ağrısı için önemli bir risk faktörü olduğu rapor edilmiştir (35).

Bel ağrısı kişinin günlük işlerini gerçekleştirebilmesinin önündeki en büyük engellerden birisidir. $\mathrm{Bu}$ sebeple bel ağrısına sahip olan bireylerin, sağlık durumlarını kötü olarak değerlendirmesi beklenmektedir (36). Çalışmamızda da genel sağlık durumunu kötü olarak algılayanlar, iyi olarak algılayanlara kıyasla daha fazla bel ağrısı şikâyetine sahipti. Literatürde de benzer sonuç bildirilmektedir (37).

Genetik faktörlerin ve ailede öğrenilen davranışların etkileri sebebiyle ailede mevcut olan bel ağrısı öyküsü, bireylerin kendilerinde de bel ağrısı oluşmasına neden olabilmektedir (38). Araştırmada anne, baba ve/veya kardeşinde bel ağrısı bulunanların bel ağrısının daha sık olduğu bulundu. Literatürde de benzer şekilde ailesinde bel ağrısı öyküsü olan sağlık çalışanlarında daha sık bel ağrısı görüldüğü bildirilmektedir (39).

Bel ağrısı ve sebep olduğu gündelik işlerin gerçekleştirilememesi, fiziksel faktörlerin yanı sıra psikososyal faktörlerden de önemli ölçüde etkilenmektedir (40). Yaptıkları işin oldukça acil ve hayati olduğu göz önünde bulundurulduğunda, hastane öncesi acil servis çalışanlarının çalışma süreleri boyunca yoğun bir stres altında ve bu yüzden de bel ağrısı ve bel ağrısının yarattığı sorunlardan en çok muzdarip olan meslek gruplarından birisi olduğu ifade edilmektedir (41). Çalışmada beklendiği gibi yüksek algılanan stres düzeyine sahip sağlık çalışanlarında bel ağrısı görülme sıklığı daha yüksek olarak bulundu. Literatürde de sağlık çalışanlarında iş yeri kaynaklı yüksek stres düzeylerinin bel ağrısı için bir risk faktörü olduğu raporlanmaktadır (29). Ancak Imani ve arkadaşlarının İran'da yaptığı bir çalışmada stres düzeyleri ve bel ağrısı arasında bir ilişkinin bulunamadığı bildirilmiştir (32). Farklı çalışma koşullarına ve kültüre sahip bireyler üzerinde yapılan çalışmalar sebebiyle farklı sonuçlar raporlanmış olabilir.

\section{SONUÇ}

Çalışma grubundaki yoğun çalışma saatleri ve zorlu iş koşulları altında çalışan sağlık çalışanlarında bel ağrısı görülme sıklığı ve stres düzeylerinin oldukça yüksek olduğu bulundu. Yüksek öğrenim düzeyi, sağlık sektöründe uzun yıllar çalışma, 24 saatlik vardiya ile çalışma, anne, baba ve kardeşlerde bel ağrısı varlığı, genel sağlık durumunu kötü algılama ve stres kişilerde bel ağrısı görülmesi için risk faktörlerindendi.

Hem fiziksel hem de psikolojik sağlık üzerinde yıpratıcı etkilere sahip bir işte çalışan ambulans servisi personellerinin karşılaştığı sorunları ortaya koyabilmek adına çok merkezli ve tüm Türkiye'yi kapsayan çalışmalar ile birlikte çözüme yönelik müdahale çalışmalarının da planlanması gerekmektedir. Stresle başa çıkma ve ergonomi konularında düzenli olarak eğitimler verilmesinin de yararlı olacağı kanısına varıldı.

\section{Kisıtlılıklar}

Çalışmanın kesitsel tipte olması, neden-sonuç iliş̧kisini ortaya koyma konusunda yetersiz kalmıştır. Çalışmada sadece tek bir ilin ambulans servisi çalışanlarının yer alması, genelleme yapılmasının önüne geçmektedir.

\section{Çıkar çatışması}

Yazarlar aralarında herhangi bir çıkar çatışması olmadığını beyan etmektedir.

\section{Teşekkür}

Eskişehir 112 İl Ambulans Servisi Başhekimliğine ve personeline yardımları ve gösterdikleri ilgiden dolayı teşekkür ederiz.

Yazarların Katkıları: Fikir/Kavram: A.K., S.Ç.P, V.G.P., D.A., A.Ü.; Tasarım: A.K., S.Ç.P, V.G.P., D.A., A.Ü.; Veri Toplama ve/veya İşleme: A.K., S.Ç.P, V.G.P., D.A., A.Ü. ; Analiz ve/veya Yorum: A.K., S.Ç.P, V.G.P., D.A., A.Ü.; Literatür Taraması: A.K., S.Ç.P, V.G.P., D.A., A.Ü.; Makale Yazımı: A.K., S.Ç.P, V.G.P., D.A., A.Ü.

\section{KAYNAKLAR}

1. Allan DB, Waddell G. An historical perspective on low back pain and disability. Acta Orthopaedica Scandinavica. 1989; 60(sup234): 1-23.

2. Maher C, Underwood M, Buchbinder R. Non-specific low back pain. The Lancet. 2017; 389(10070): 73647.

3. Walker BF. The prevalence of low back pain: a systematic review of the literature from 1966 to 1998. Clinical Spine Surgery. 2000; 13(3): 205-17. 
4. Erdine S, Hamzaoğlu O, Özkan Ö, Balta E, Domaç M. Türkiye'de erişkinlerin ağrı prevalansı. Ağrı Dergisi. 2001; 13(2): 22-30.

5. Altinel L, Kose KC, Ergan V, Isik C, Aksoy Y, Ozdemir A, et al. The prevalence of low back pain and risk factors among adult population in Afyon region, Turkey. Acta Orthop Traumatol Turc. 2008; 42(5): 328-33.

6. Özdemir F, Karaoğlu L, Özfırat Ö. Malatya il merkezinde yaşayan bireylerde boyun, sirt ve bel ağrısı prevalansları ve etkileyen faktörler. Ağrı Dergisi. 2013; 25(1): 27-35.

7. Hartvigsen J, Hancock MJ, Kongsted A, Louw Q, Ferreira ML, Genevay S, et al. What low back pain is and why we need to pay attention. The Lancet. 2018; 391(10137): 2356-67.

8. Vos T, Lim SS, Abbafati C, Abbas KM, Abbasi M, Abbasifard M, et al. Global burden of 369 diseases and injuries in 204 countries and territories, 19902019: a systematic analysis for the Global Burden of Disease Study 2019. The Lancet. 2020; 396(10258): 1204-22.

9. İçağasığlu A, Yumuşakhuylu Y, Ketenci A, Toraman NF, Karataş GK, Kuru Ö, et al. Kronik bel ağrısının türk toplumuna maliyeti. Turkish Journal of Physical Medicine \& Rehabilitation/Turkiye Fiziksel Tip ve Rehabilitasyon Dergisi, 2015; 61(1): 58-64.

10. Yilmaz E, Dedeli O. Effect of physical and psychosocial factors on occupational low back pain. Health Science Journal. 2014; 6(4): 598-609.

11. Eriksen W, Bruusgaard D, Knardahl S. Work factors as predictors of intense or disabling low back pain; a prospective study of nurses' aides. Occupational and environmental medicine. 2004; 61(5): 398-404.

12. Kaila-Kangas L, Kivimäki $M$, Riihimäki $H$, Luukkonen R, Kirjonen J, Leino-Arjas P. Psychosocial factors at work as predictors of hospitalization for back disorders: a 28-year followup of industrial employees. Spine. 2004; 29(16): 1823-30.

13. Frymoyer JW, Pope MH, Costanza MC, Rosen JC, Goggin JE, Wilder DG. Epidemiologic studies of lowback pain. Spine. 1980; 5(5): 419-23.

14. Karasek R. Stress prevention through work reorganization: A summary of 19 international case studies. International Labour Office: Conditions of Work Digest. 1992; 11: 23-41.

15. Mekonnen TH. Work-related factors associated with low back pain among nurse professionals in east and west Wollega zones, Western Ethiopia, 2017: a crosssectional study. Pain and therapy. 2019; 8(2): 239-47.

16. Lorusso A, Bruno S, L'abbate N. A review of low back pain and musculoskeletal disorders among Italian nursing personnel. Industrial health. 2007; 45(5): 637-44.

17. Fischer SL, Sinden KE, MacPhee RS. Identifying the critical physical demanding tasks of paramedic work: Towards the development of a physical employment standard. Applied ergonomics. 2017; 65: 233-9.

18. Stratford PW, Binkley JM, Riddle DL. Development and initial validation of the back pain functional scale. Spine. 2000; 25(16): 2095-102.
19. Meltem K, Bayar K. Fonksiyonel Bel Ağrıs1 Skalası'nın Türkçe uyarlaması: geçerlik ve güvenirlik çalışması. Journal of Exercise Therapy and Rehabilitation. 2017; 4(2): 82-9.

20. Cohen S, Kamarck T, Mermelstein R. A global measure of perceived stress. Journal of health and social behavior. 1983: 385-96.

21. Eskin M, Harlak H, Demirkıran F, Dereboy Ç, editors. Algılanan stres ölçeğinin Türkçeye uyarlanması: güvenirlik ve geçerlik analizi. New/Yeni Symposium Journal; 2013.

22. Şimşek Ş, Yağcı N, Şenol H. Denizli'de sağlık çalışanlarında bel ağrısı prevelansı ve risk faktörleri. Ağr1 Dergisi. 29(2): 71-8.

23. Tezel A. Musculoskeletal complaints among a group of Turkish nurses. International Journal of Neuroscience. 2005; 115(6): 871-80.

24. Karahan A, Kav S, Abbasoglu A, Dogan N. Low back pain: prevalence and associated risk factors among hospital staff. Journal of advanced nursing. 2009; 65(3): 516-24.

25. Hoy D, Brooks P, Blyth F, Buchbinder R. The epidemiology of low back pain. Best practice \& research Clinical rheumatology. 2010; 24(6): 769-81.

26. Nyland LJ, Grimmer KA. Is undergraduate physiotherapy study a risk factor for low back pain? A prevalence study of LBP in physiotherapy students. BMC musculoskeletal disorders. 2003; 4(1): 1-12.

27. Ogunlana M, Davis O, Thanni A, Lateef R, Solabi A, Alimi T, et al. Determinants of Low Back Pain Disability Among Hospital Workers. Journal of the Nigeria Society of Physiotherapy. 2012; 20: 15-20.

28. Atik D, Cander B, Dikmetas C, Bulut B, Gokcen E, Caltekin İ, et al. Evaluation of low back pain prevalence in emergency department workers. Eurasian Journal of Critical Care. 2018; 2(1): 145-52.

29. Rahimi A, Vazini H, Alhani F, Anoosheh M. Relationship between low back pain with quality of life, depression, anxiety and stress among emergency medical technicians. Trauma monthly. 2015; 20(2): e18686

30. Dionne C, Von Korff M, Koepsell T, Deyo R, Barlow W, Checkoway H. Formal education and back pain: a review. Journal of Epidemiology \& Community Health. 2001; 55(7): 455-68.

31. Li JY, Sheng W, He LH, Wu SS, Lei Y, Yu SF, et al. Risk factors of low back pain among the Chinese occupational population: a case-control study. Biomedical and Environmental Sciences. 2012; 25(4): 421-9.

32. Imani A, Borna J, Alami A, Khosravan S, Hasankhani $\mathrm{H}$, Bafandeh Zende M. Prevalence of low back pain and its related factors among pre-hospital emergency personnel in Iran. Journal of Emergency Practice and Trauma. 2019; 5(1): 8-13.

33. Alnaami I, Awadalla NJ, Alkhairy M, Alburidy S, Alqarni A, Algarni A, et al. Prevalence and factors associated with low back pain among health care workers in southwestern Saudi Arabia. BMC musculoskeletal disorders. 2019; 20(1): 1-7

34. Hoogendoorn WE, Bongers PM, De Vet HC, Douwes M, Koes BW, Miedema MC, et al. Flexion and rotation of the trunk and lifting at work are risk 
factors for low back pain: results of a prospective cohort study. Spine. 2000; 25(23): 3087-92.

35. Coenen P, Gouttebarge V, van der Burght AS, van Dieën JH, Frings-Dresen MH, van der Beek AJ, et al. The effect of lifting during work on low back pain: a health impact assessment based on a meta-analysis. Occupational and environmental medicine. 2014; 71(12): 871-7.

36. Takeyachi Y, Konno S-i, Otani K, Yamauchi K, Takahashi I, Suzukamo Y, et al. Correlation of low back pain with functional status, general health perception, social participation, subjective happiness, and patient satisfaction. Spine. 2003; 28(13): 1461-6.

37. Zhang Q, Dong H, Zhu C, Liu G. Low back pain in emergency ambulance workers in tertiary hospitals in China and its risk factors among ambulance nurses: a cross-sectional study. BMJ open. 2019; 9(9): e029264.

38. El-Metwally A, Mikkelsson M, Ståhl M, Macfarlane GJ, Jones GT, Pulkkinen L, et al. Genetic and environmental influences on non-specific low back pain in children: a twin study. European Spine Journal. 2008; 17(4): 502-8.

39. Altınel L, Köse KÇ, Altınel EC. Profesyonel hastane çalışanlarında bel ağrısı prevelansı ve bel ağrısını etkileyen faktörler. Tıp Araştırmaları Dergisi. 2007; 5(3): 115-20.

40. Hartvigsen J, Lings S, Leboeuf-Yde C, Bakketeig L. Psychosocial factors at work in relation to low back pain and consequences of low back pain; a systematic, critical review of prospective cohort studies. Occupational and environmental medicine. 2004; 61(1): e2-e.

41. Hammer JS, Mathews JJ, Lyons JS, Johnson NJ. Occupational stress within the paramedic profession: an initial report of stress levels compared to hospital employees. Annals of emergency medicine. 1986; 15(5): 536-9. 